\title{
Improved regional scale processes reflected in projected hydrological changes over large European catchments
}

\author{
Stefan Hagemann · Holger Göttel · Daniela Jacob • \\ Philip Lorenz $\cdot$ Erich Roeckner
}

Received: 4 November 2007/Accepted: 24 March 2008/Published online: 18 April 2008

(C) The Author(s) 2008

\begin{abstract}
For the fourth assessment report of the Intergovernmental Panel on Climate Change (IPCC), the recent version of the coupled atmosphere/ocean general circulation model (GCM) of the Max Planck Institute for Meteorology has been used to conduct an ensemble of transient climate simulations These simulations comprise three control simulations for the past century covering the period 1860-2000, and nine simulations for the future climate (2001-2100) using greenhouse gas (GHG) and aerosol concentrations according to the three IPCC scenarios B1, A1B and A2. For each scenario three simulations were performed. The global simulations were dynamically downscaled over Europe using the regional climate model (RCM) REMO at $0.44^{\circ}$ horizontal resolution (about $50 \mathrm{~km}$ ), whereas the physics packages of the GCM and RCM largely agree. The regional simulations comprise the three control simulations (1950-2000), the three A1B simulations and one simulation for B1 as well as for A2 (2001-2100). In our study we concentrate on the climate change signals in the hydrological cycle and the $2 \mathrm{~m}$ temperature by comparing the mean projected climate at the end of the twenty-first century (2071-2100) to a control period representing current climate (1961-1990). The robustness of the climate change signal projected by the GCM and RCM is analysed focussing on the large European catchments of Baltic Sea (land only), Danube and Rhine. In this respect, a robust climate change signal designates a projected change that sticks out of the noise of
\end{abstract}

S. Hagemann $(\bowtie) \cdot$ H. Göttel · D. Jacob · P. Lorenz ·

E. Roeckner

Max Planck Institute for Meteorology, Bundesstr. 53,

20146 Hamburg, Germany

e-mail: stefan.hagemann@zmaw.de natural climate variability. Catchments and seasons are identified where the climate change signal in the components of the hydrological cycle is robust, and where this signal has a larger uncertainty. Notable differences in the robustness of the climate change signals between the GCM and RCM simulations are related to a stronger warming projected by the GCM in the winter over the Baltic Sea catchment and in the summer over the Danube and Rhine catchments. Our results indicate that the main explanation for these differences is that the finer resolution of the RCM leads to a better representation of local scale processes at the surface that feed back to the atmosphere, i.e. an improved representation of the land sea contrast and related moisture transport processes over the Baltic Sea catchment, and an improved representation of soil moisture feedbacks to the atmosphere over the Danube and Rhine catchments.

Keywords Regional climate change .

Hydrological cycle · European catchments .

GCM and RCM ensembles · Robustness

\section{Introduction}

The climate of the Earth is influenced by increasing greenhouse gas (GHG) concentrations, changing aerosol compositions and loads as well as by land surface changes. Global climate models are investigating possible trends in future global climate through the development of climate change scenarios. These follow specific assumptions for the evolution of GHG and aerosols, several of which have been defined by the Intergovernmental Panel on Climate Change (IPCC; Houghton et al. 2001) and are described in the IPCC Special Report on Emission Scenarios (SRES, Nakicenovic et al. 2000). 
The hydrological cycle is crucially important to life on Earth. The general circulation of the atmosphere is driven largely by the release of latent heat due to rain and snow formation. At longer time-scales, the hydrological cycle affects the groundwater storage, the thermohaline circulation in the ocean and the evolution of glaciers and ice sheets. Hydrological regimes vary accordingly to local and regional climate variations. Looking towards future climate, the projected climate change in the mean and in the variability will in turn produce changes in hydrological conditions. Thus, an adequate representation of the hydrological cycle, its future development and associated uncertainties are key issues in studies of global and regional climate change (e.g. Cubasch et al. 2000). In this context, it must be noted that hydrological fluxes depend on processes that are generally several orders of magnitude smaller than the typical grid-size used in current general circulation models (GCMs) and in current regional climate models (RCMs). Consequently the importance of the hydrological cycle is highlighted by the Global Energy and Water Cycle Experiment (GEWEX; e.g. Sorooshian et al. 2005). The implications of changes in the hydrological cycle induced by climate change may affect the society more than any other changes, e.g. with regard to flood risks, water availability and water quality.

Due to the lack of computer power, global climate models are generally still not able to represent surface heterogeneities on scales less than about $100 \mathrm{~km}$ grid length. However, global climate change has an influence on these local and regional scales, which will be experienced by man-kind directly (Christensen et al. 2007). Improved knowledge on regional climate change can be achieved with the use of different regionalization techniques, including high-resolution and variable resolution GCMs (Cubasch et al. 1995; Déqué and Piedelievre 1995), nested RCMs (Giorgi and Mearns 1999), and statistical downscaling (Wilby et al. 1998). RCMs are used for the dynamical downscaling of the global scale GCM simulations to regional scales (e.g., Giorgi 2006). Climate simulations performed with GCMs provide a consistent representation of the large-scale global circulation in both the atmosphere and the ocean, while RCMs introduce more details to the atmospheric simulations due to regional features such as topography and inland seas (Rummukainen et al. 2001). In both cases, simulations are usually produced for a control climate representing present-day climate conditions and for future climates representing various emission scenarios.

For the hydrological cycle simulated by coupled atmosphere-ocean GCMs and RCMs and its projected future changes, several kinds of uncertainties exists. There is uncertainty in the GHG and aerosol concentrations based on the different IPCC SRES scenarios, uncertainty due to the choice of the climate model as each model uses different techniques to discretize the dynamical equations and to parameterize sub-grid effects, uncertainty due to natural climate variability, and for RCMs the uncertainty in the GCM forcing at the lateral boundaries. The importance of the sources of uncertainty varies between GCMs and RCMs (see Déqué et al. 2007), and depends also on the climatological field, the region and the season. Results of Déqué et al. (2007) indicated that regarding uncertainty based on several models, the number of GCM forcings involved is at least as important as the number of RCMs. They stressed also the importance of considering several scenarios, at least in the case of future southern Europe summer warming.

A major effort to understand uncertainties in regional climate modelling has been undertaken in the EU project PRUDENCE (Prediction of Regional scenarios and Uncertainties for Defining EuropeaN Climate change risks and Effects), which aimed to predict uncertainties in RCM simulations over Europe (Christensen and Christensen 2007). Here, 10 RCMs were forced with observed sea surface temperature (SST) and lateral boundary conditions provided by the GCM HadAM3H (Pope et al. 2000). Within PRUDENCE, several studies using the output from the RCM ensemble were conducted. Among these studies, Hagemann and Jacob (2007) evaluated the simulated hydrological cycle of the ten RCMs and the reduction of uncertainty in the future projections by considering the multi-model ensemble mean over the catchments of the Baltic Sea (land area only), Danube and Rhine. First results considering two different scenarios and two different GCM forcings were obtained with the RCM RCAO (Räisänen et al. 2004) within the PRUDENCE project. Here, the four simulations agreed on a general increase in precipitation in northern Europe, especially in winter, and on a general decrease in precipitation in southern and central Europe in summer. However, the magnitude and the geographical patterns of the change differed considerably between the two GCM forcings. Rowell (2006) made an initial attempt to estimate the uncertainty that arises from typical variations in RCM formulation, focussing on projected changes in surface air temperature and precipitation over the UK. It was found that the largest source of uncertainty, for both variables and in all seasons, is the formulation of the forcing GCM.

Also within PRUDENCE, Rowell (2005) firstly analysed projected seasonal changes in temperature, precipitation and snow mass over Europe from a three member ensemble $(3 *$ control, $3 * \mathrm{~A} 2$ scenario) of 30 year time slice simulations conducted with the GCM HadAM3P (Pope et al. 2000) regarding statistical significance. Here, the mean precipitation anomalies in the future scenario are dominated (to first order and in all seasons) by a large-scale 
pattern of enhanced precipitation in the north and reduced precipitation in the south. However, the boundary between these two regimes displays a sizable annual cycle, such that it is located at about $40^{\circ} \mathrm{N}$ in winter, $45^{\circ} \mathrm{N}$ in spring, $60^{\circ} \mathrm{N}$ in summer and $55^{\circ} \mathrm{N}$ in autumn. Kennett et al. (2008) used a three-member ensemble of the RCM HadRM3H to study the robustness of projected changes in extreme precipitation at the grid box level over Europe.

In the present study, we use a large ensemble of 12 transient coupled atmosphere-ocean GCM simulations ( $3 *$ control, three for each of B1, A1B and A2) and eight RCM simulations $(3 *$ control, $3 * \mathrm{~A} 1 \mathrm{~B}, 1 * \mathrm{~B} 1,1 * \mathrm{~A} 2)$ that have been conducted at the Max Planck Institute for Meteorology (MPI-M). The aim of the study is to investigate how robust the projected changes in the hydrological cycle of the MPI-M climate models are compared to the natural climate variability as it is represented in both models. Further we will address the question whether the robustness of the climate change signal differs between the GCM and the RCM forced by the GCM. In order to answer these questions we have focused on large European catchments, especially on the Baltic Sea, Danube and Rhine catchments, which are representing different climate conditions (see Sect. 2.3).

The method to investigate the robustness of projected climate change is described in Sect. 2 where also brief descriptions of the climate simulations used in the present study are given. Sections 3 and 4 consider the projected annual and monthly changes, respectively, and regions and seasons are identified where the climate change signal in the hydrological cycle is robust. Noticeable differences between the GCM and the RCM projections are discussed in Sect. 5, and finally Sect. 6 gives some conclusions.

\section{Methods}

Section 2.1 briefly describes the GCM and RCM simulations considered in the present study, and notes the main differences in the physical parameterizations of both models. Section 2.2 considers the method used to find robust projected climate changes, and Sect. 2.3 shortly introduces the European catchments this study is focusing on.

\subsection{Climate model simulations}

For the fourth assessment report of the IPCC, the coupled atmosphere/ocean GCM ECHAM5/MPIOM (Roeckner et al. 2003; Jungclaus et al. 2006) has been used to conduct an ensemble of climate simulations. These simulations comprise three control simulations for the past century covering the period 1860-2000, and nine simulations for the future climate (2001-2100). The coupled model was run without flux correction at T63 (about $1.9^{\circ}$ or $200 \mathrm{~km}$ grid size) horizontal resolution and 31 vertical levels in the atmosphere, and about $1.5^{\circ}$ horizontal resolution and 40 vertical layers in the ocean. For the past climate (18602000), observed concentrations of $\mathrm{CO}_{2}, \mathrm{CH}_{4}, \mathrm{~N}_{2} \mathrm{O}, \mathrm{CFCs}$, $\mathrm{O}_{3}$ (tropospheric and stratospheric), and sulphate aerosols were prescribed, thereby considering the direct and first indirect aerosol effect. Three realizations were yielded by the use of slightly different initial conditions at the start of the simulations in 1860 . For the future climate (20012100) these concentrations were prescribed according to the three IPCC scenarios B1, A1B and A2 (Nakicenovic et al. 2000). Here, for each scenario three simulations were performed using the initial conditions in 2001 taken from the three different control simulations. These global simulations were dynamically downscaled over Europe using the RCM REMO (Jacob 2001) at $0.44^{\circ}$ horizontal resolution (about $50 \mathrm{~km}$ ). The regional simulations comprise the three control simulations (1950-2000), the three A1B simulations and one simulation for $\mathrm{B} 1$ as well as for $\mathrm{A} 2$ (2001-2100).

The physics packages of ECHAM5 and REMO largely agree as REMO uses mainly the ECHAM4 physics package (Roeckner et al. 1996). Notable differences are: In ECHAM5 a new scheme for stratiform clouds was implemented that includes prognostic equations for the water phases (vapor, liquid, solid), bulk cloud microphysics (Lohmann and Roeckner 1996), and a statistical cloud cover scheme with prognostic equations for the distribution moments (Tompkins 2002). In the used REMO version the cloud ice content is calculated diagnostically. The vegetation dependent land surface parameters in both models are taken from the LSP2 dataset (Hagemann 2002). However, ECHAM5 uses a time invariant snow free surface background Albedo, while REMO uses a prescribed seasonal cycle according to Rechid et al. (2008). In ECHAM5 a prognostic equation for the amount of snow on the canopy has been introduced, and the calculation of the surface albedo over snow covered areas was modified (Roesch et al. 2001). ECHAM5 operates with a discrete (0/1) land sea mask, while REMO utilizes a fractional distribution of land, water and sea ice whereas the vertical fluxes at the atmosphere-surface interface are calculated separately for the different compartments within a model gridbox (Semmler et al. 2004). In REMO the improved Arno scheme (Hagemann and Dümenil Gates 2003) is implemented to represent the separation of rainfall and snow melt into surface runoff and infiltration, which is a further development of the Arno scheme (Dümenil and Todini 1992) used in ECHAM5. 


\subsection{Robustness of projected changes}

In our study we focus on the $2 \mathrm{~m}$ temperature and the components of the hydrological cycle in a control period (1961-1990) representing current climate, and in a future period (2071-2100) representing a possible climate in the end of the twenty-first century. In order to consider projected future changes, we will compare the ensemble means of the three scenarios for this future period to the ensemble mean of the control period. In order to consider the robustness of the climate change signal, we compare the mean change of each scenario to the maximum spread within all scenarios and within the control simulation, which is taken to represent the natural climate variability.

In the following, we give a more detailed description of this method, which is also schematically shown in Fig. 1. For a given variable $P$ we first calculated the 30-year average for each month over the chosen period. This was done for each climate simulation. Then, these climatological averages were interpolated from the climate model grid to a regular $0.5^{\circ}$ grid where they were integrated over different large European catchment areas. The catchment areas were taken from a modified $0.5^{\circ}$ catchment dataset of Hagemann and Dümenil (1998). For each of the ensembles $X($ Control $=\mathrm{C} 20$, Scenarios $=\mathrm{B} 1, \mathrm{~A} 1 \mathrm{~B}, \mathrm{~A} 2)$, an ensemble mean $\mu_{P, X}$ and a standard deviation $\sigma_{P, X}$ could be obtained. For a specific scenario $F$, the projected change $\Delta P_{F}$ of a hydrological variable is defined relative to the mean $\mu_{P, C 20}$ of the control period: $\Delta P_{F}=\left(\mu_{P, F}-\mu_{P, C 20}\right) /$ $\mu_{P, C 20}$. The natural climate variability is supposed to be represented by the maximum spread $S$ within each of the scenarios and within the control simulation. $S$ is also defined relative to the corresponding mean of the control period: $S=\operatorname{Max}\left(\sigma_{P, C 20}, \sigma_{P, B 1}, \sigma_{P, A 1 B},\left(\sigma_{P, A 2}\right) / \mu_{P, C 20}\right.$. A projected change $\Delta P_{F}$ is considered as robust if $\Delta P_{F}>S$, i.e. the robustness $r=\Delta P_{F} / S>1$. Thus, no robust signal means that the projected change is within the noise of natural climate variability. For the temperature $T$ only the absolute changes and spreads are considered, i.e. $\Delta T_{F}=\left(\mu_{T, F}-\mu_{T}\right.$, $\left.{ }_{C 20}\right)$ and $S=\operatorname{Max}\left(\sigma_{T, C 20}, \sigma_{T, B 1}, \sigma_{T, A l B}, \sigma_{T, A 2}\right)$.

Note that the chosen definition of $S$ is somewhat limited. Ideally, a large ensemble (e.g. 10) would be desirable for the control period and for each of the scenarios. However, due to the very large requirements in computing time, it was impossible to achieve such a large number of climate model simulations. A standard deviation estimated from a sample of three members is of course a poor estimator. But on the one hand the standard deviation is calculated from 30 -years averages. On the other hand the overestimation of the true natural variability (or spread) by one three-member standard deviation has the same probability as an underestimation. Hence, we choose the maximum standard deviation $S$ out of four three-member ensembles as a

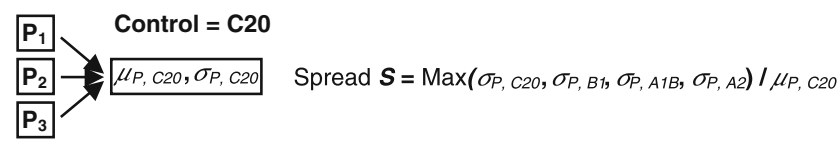

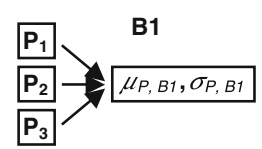

The same as for $\mathbf{B} 1$ applies to the scenarios A1B and $\mathbf{A} 2$.

Fig. 1 Schematic description of the method to define a robust climate change signal in the variable $P$. (Note that for the temperature $T$ only the absolute changes $\Delta$ ( and spreads are considered, i.e. no division by $\mu T,{ }_{C 20}$, and for the RCM, the spread is calculated from the control and the A1B scenario simulations.]

critical measure, which very likely causes an overestimation of the true spread. Thus, a "robust" signal $\left(\Delta P_{F}>S\right)$ yielded by the method described above is also very likely robust. Although the spread $S$ for the RCM is only based on two three-member ensembles it shows a similar behaviour as the GCM spread, which also gives some confidence in the robustness criteria for the RCM signals.

\subsection{Study areas}

As mentioned above, in order to investigate the robustness of projected changes in the hydrological cycle, several large European catchments are considered (Fig. 2), i.e. the Baltic Sea catchment (about 1.8 Million $\mathrm{km}^{2}$; land points only are considered in the following if not stated otherwise) representing a maritime climate since it is water-dominated by advection from the ocean and from the Baltic Sea, the Danube catchment (about $800,000 \mathrm{~km}^{2}$ ) representing a continental climate as it is land-dominated by advection from the surrounding land areas, and the Rhine catchment (about $160,000 \mathrm{~km}^{2}$ ) that is located in a transition zone of both climates. The latter is also largely influenced by Alpine snow processes and climate. All catchments were

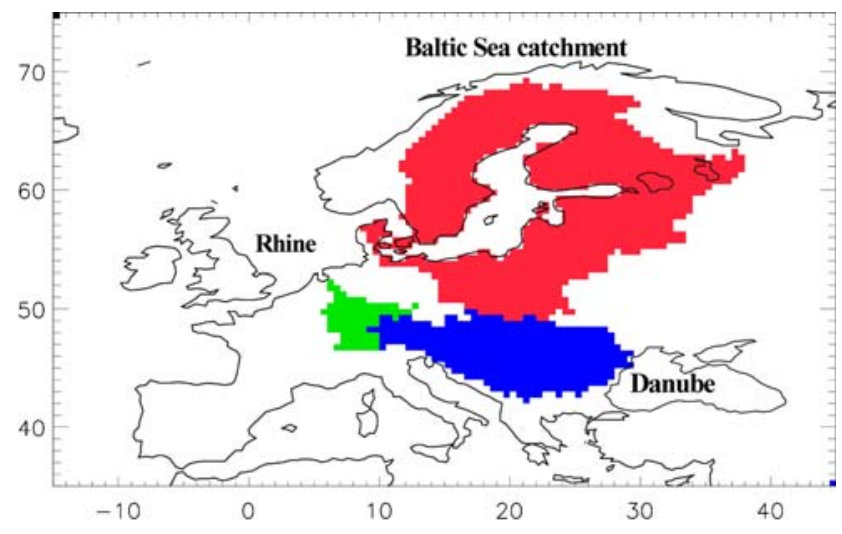

Fig. 2 Large European river catchments at $0.5^{\circ}$ resolution 
also considered in previous hydrological studies focusing on model evaluation of the atmospheric GCM ECHAM5 (Hagemann et al. 2006), and of several RCMs including REMO in the European MERCURE project (Hagemann et al. 2004) as well as in several studies within the PRUDENCE project (e.g. Graham et al. 2007; Hagemann and Jacob 2007; Hirschi et al. 2007; Van den Hurk et al. 2005). Since the climate change results of the MPI-M models for the Elbe catchment (about $145,000 \mathrm{~km}^{2}$ ) are very similar to the Rhine catchment, the Elbe is not considered in this study.

\section{Annual signals}

Figure 3 summarizes the projected annual ensemble mean changes between the two 30-years periods (cf. Sect. 2.2) in the hydrological cycles for the considered catchments.
Here, only the scenario simulations are considered where an ensemble of three simulations was performed (GCM: B1, A1B, A2; RCM: A1B). While the upper panel shows the projected changes, the lower panel shows the robustness $r$ (see Sect. 2.2) of these changes whereas a change is considered as robust if $r>1$. For the Baltic Sea catchment, both GCM and RCM show robust increases in precipitation, evapotranspiration and runoff pointing to a general enhancement of the hydrological cycle in this region. Remarkably the RCM's projected increase in evapotranspiration is much lower than those projected for the different scenarios by the GCM (see Sect. 5.1 for a more detailed discussion), which leads to a much stronger increase in runoff projected by the RCM. For the GCM, the projected increases in runoff are robust only for A1B and A2, even though the projected change is close to the spread. For the Danube, the GCM projects a robust decrease in precipitation and runoff for all scenarios, whereas the latter is not
Fig. 3 Climate change signals (upper panel) and their robustness $r$ (lower panel) of the terrestrial water balance $(P$, Prec. Precipitation, E, Evap. evapotranspiration, $R$, Run. Runoff) for 2071-2100 compared to 1961-1990. P, E and R RCM denote the changes yielded by the RCM REMO. All other changes are obtained by the GCM ECHAM5/MPIOM. A signal is considered as robust if $r>1$
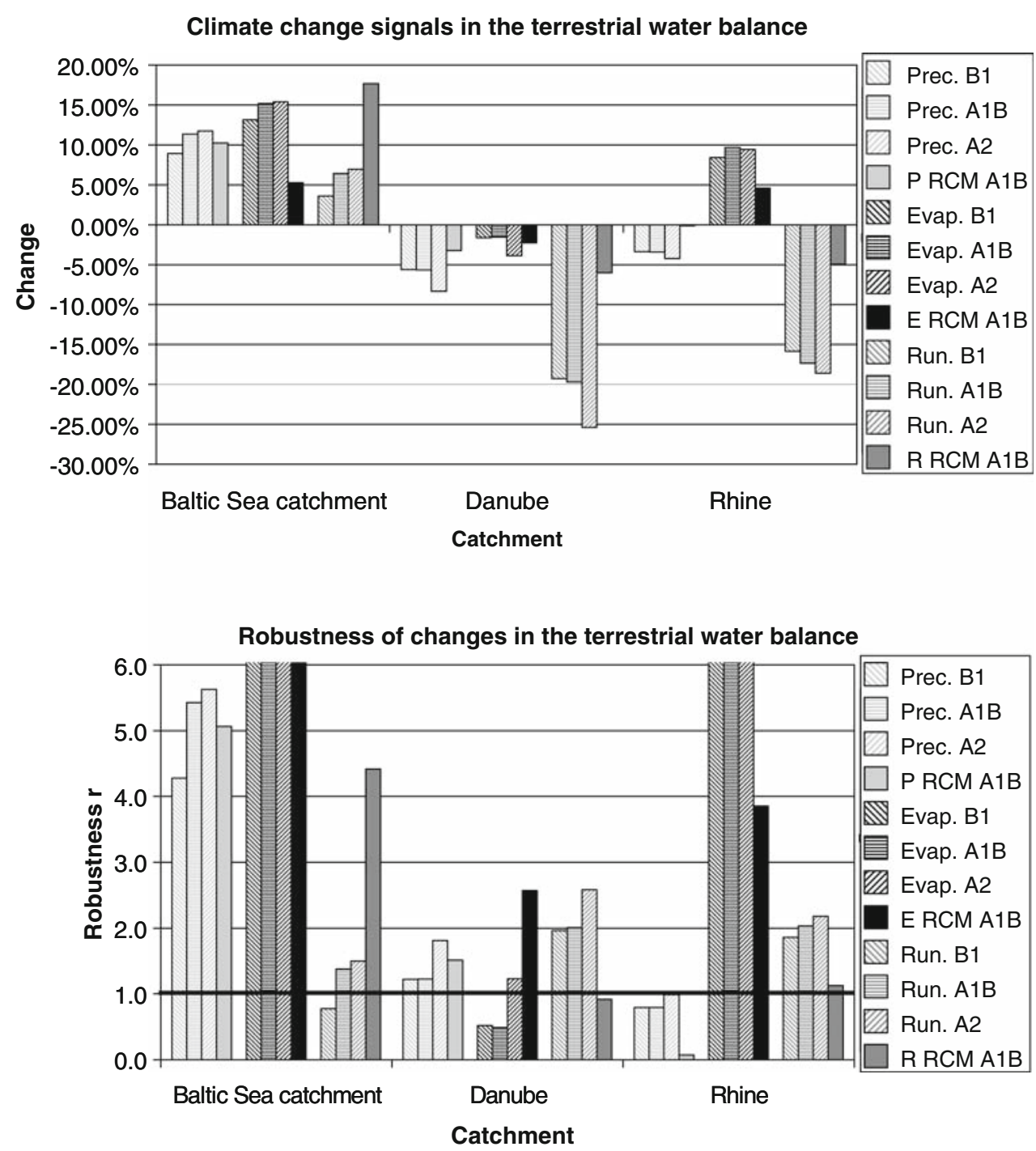
robust in the RCM's A1B scenario. The RCM instead shows a robust decrease in evapotranspiration although this signal is relatively small. For the Rhine, there is a robust increase in evapotranspiration that is lower in the RCM A1B scenario than in the GCM scenarios. Similar to the Danube catchment, the GCM projects a robust runoff decrease that in contrary to the Danube is also robust in the RCM's A1B scenario although the RCM signal is comparatively small compared to the GCM. Differences in the results for the Danube and the Rhine catchments will also be discussed in Sect. 5.2.

The examination of the annual mean changes suggests that differences in the projected evapotranspiration changes between the GCM and RCM lead to differences in the projected runoff changes and their robustness. Although for some variables in some catchments no robust climate change signals are yielded, there might be seasonal varying robust changes as will be shown in Sect. 4 .

\section{Monthly signals}

Figure 4 shows that the monthly climate change signals of $2 \mathrm{~m}$ temperature are fairly robust for all months and all catchments. For the Baltic Sea catchment the maximum temperature increase is projected for the winter while a maximum increase in the summer is shown for the Danube.
A noticeable difference between the GCM and the RCM can be seen in the strength of the projected warming in the season with maximum temperature increase. Here, the projected temperature change by the GCM is about $1 \mathrm{~K}$ larger than projected by the RCM. For the Rhine, results similar to the Danube are yielded (not shown).

The projected precipitation changes (Fig. 5) largely agree between the GCM and the RCM for the Baltic Sea catchment, with robust increases from September-April. In the winter, the GCM projects a somewhat stronger increase than the RCM, which seems to be directly related to the stronger winter warming in the GCM simulations (Fig. 4). A warmer atmosphere is able to store more moisture, and consequently more water may be released during a precipitation event. Note that the RCM precipitation change curve (Fig. 5) for the A1B ensemble mean is much smoother than for the RCM's single realizations of the B1 and A2 scenarios. This reflects the importance to use ensemble simulations instead of only one simulation (or alternative approaches) to pay regard to natural climate variability, if adequate climate change projections for specific regions are intended. For the Danube catchment (as well as for the Rhine catchment - not shown), both GCM and RCM project a robust future summer time drying, whereas the projected decrease in precipitation is much more pronounced in the GCM than in the RCM. This directly coincides with the stronger warming in the summer projected by the GCM.
Fig. 4 Monthly mean temperature changes (20712100 compared to 1961-1990) over the Baltic Sea (upper panels) and Danube catchments (lower panels) as projected by the GCM ECHAM5/MPIOM (left panels) and the RCM REMO (right panels). Max Std denotes the maximum spread $S$ for the corresponding ensembles
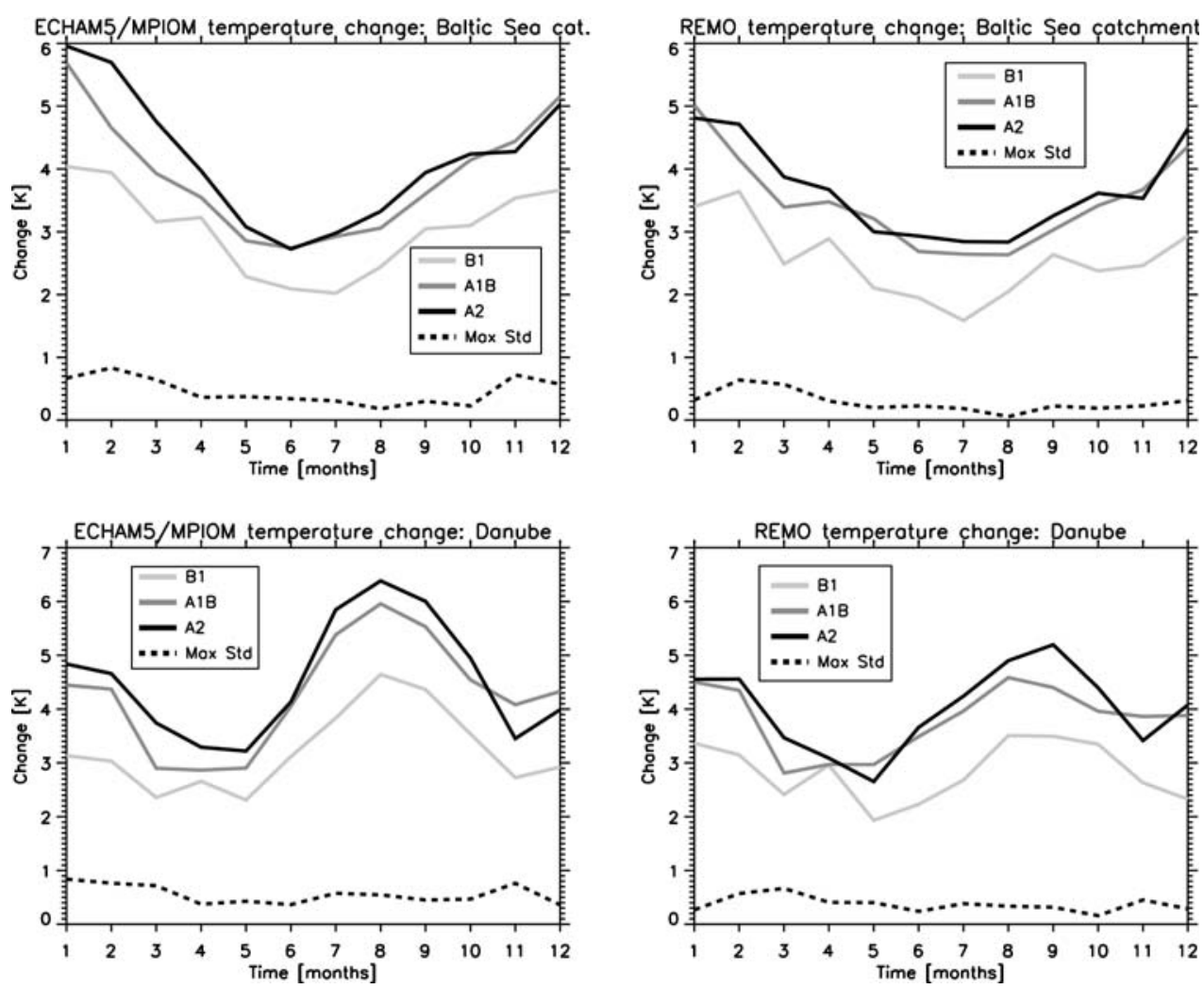
Fig. 5 Monthly mean precipitation changes (20712100 compared to 1961-1990) over the Baltic Sea (upper panels) and Danube catchments (lower panels) as projected by the GCM ECHAM5/MPIOM (left panels) and the RCM REMO (right panels). Max Std denotes the maximum spread $S$ for the corresponding ensembles
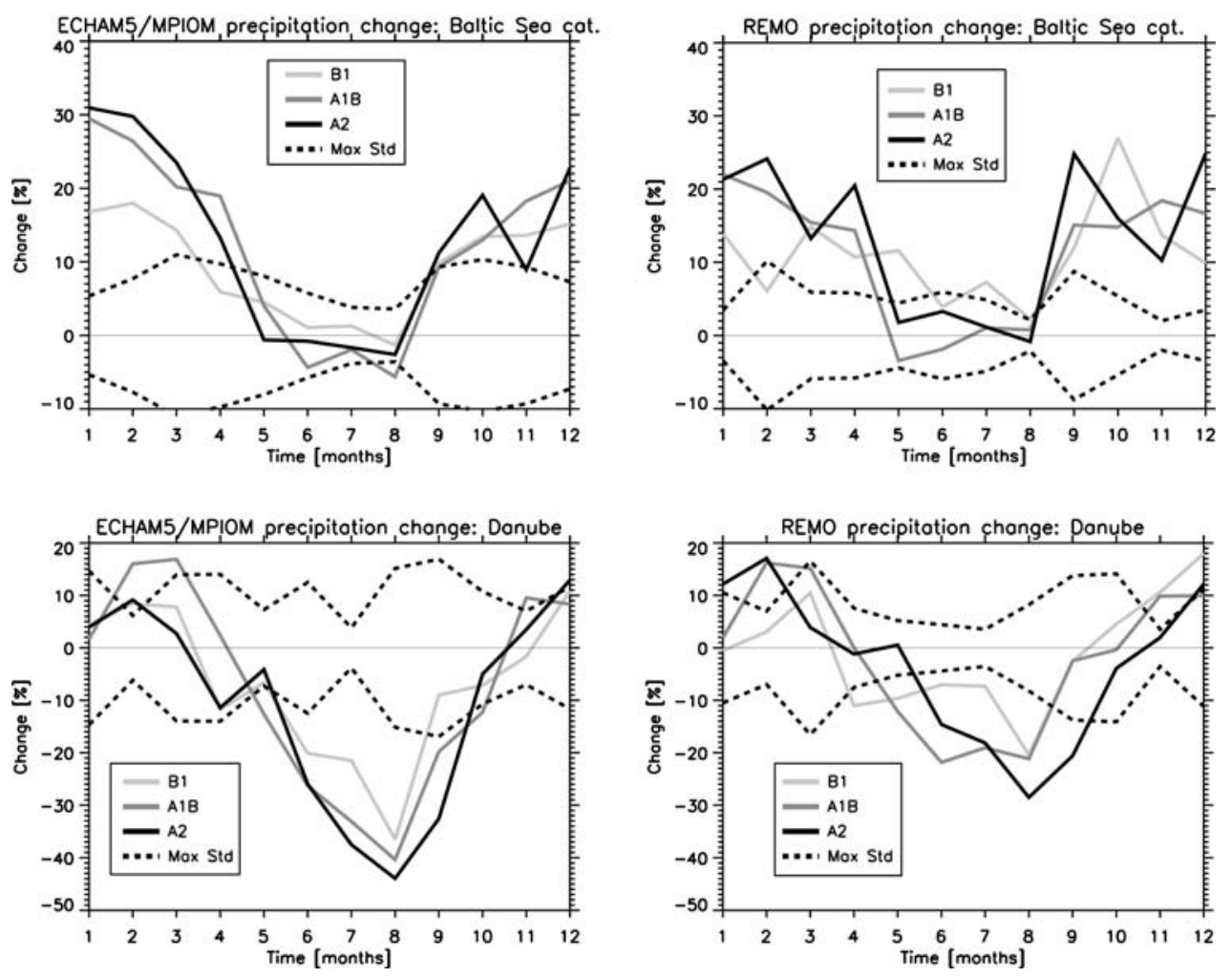

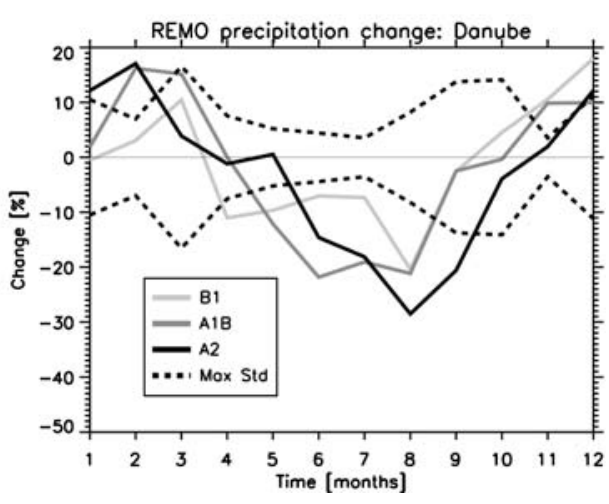

For the Baltic Sea catchment, both GCM and RCM show robust increases in evapotranspiration (Fig. 6) throughout the year except for the summer in the RCM. But the relative increase in evapotranspiration is much stronger in the GCM, especially during winter time. This notable difference will be discussed in detail in Sect. 5.1. The projected reduction of precipitation (Fig. 5) in the summer over the Danube catchment leads to a drying of this region. Consequently, less moisture is available for evapotranspiration, which is indicated by the projected reduction of evapotranspiration (Fig. 6) in the late summer and autumn. Here, the stronger reduction in the GCM is consistent with its projected stronger reduction in precipitation (Fig. 5). In addition, the GCM projects robust increases of evapotranspiration during the winter and spring, which are confined to the spring by the RCM. For the Rhine, robust increases of evapotranspiration (Fig. 6) are projected by the GCM and the RCM in the winter and spring, whereas the spring increases are relatively small, especially in the RCM. Here, the GCM projects a robust increase also in the summer and a decrease in the late autumn. As for the Danube, the latter is clearly related to the drying of the region induced by the strong reduction in summer time precipitation. But different to the Danube, this reduction in evapotranspiration occurs much later in the year for the GCM and the RCM projects no reduction at all, although the projected reduction in precipitation is very similar in both catchments. This indicates (see also Sect.
5.2) a larger buffer capacity of soil water reservoirs (snow pack, soil moisture) in the Rhine catchment.

Finally, the projected changes in precipitation and evapotranspiration blend into the changes of runoff shown in Fig. 7. For the Baltic Sea catchment, the GCM and RCM agree in the general shape of robust runoff changes with a reduction in April and May, and robust increases in autumn and winter. Though, these increases are larger in the RCM than in the GCM. This seems to be linked to the lower evapotranspiration increase in the RCM, which has also led to the robust increase in the annual mean runoff mentioned in Sect. 3.

For the Danube and the Rhine catchments, the projected reduction in summer precipitation leads to robust reductions in runoff (Fig. 7). Here, the GCM shows a strong reduction in runoff from May to December that is largest in the summer, and where the robust decrease is even extended to all months except for April for the A2 scenario over the Danube catchment. The RCM projects a much smaller reduction that is robust from May to October for the A1B scenario, and robust for even fewer months in the B1 and A2 (except for the Rhine) scenario. But the smoothness of the ensemble mean A1B curve compared to the single realizations of $\mathrm{B} 1$ and $\mathrm{A} 2$, again indicates the influence of natural climate variability on the projected changes obtained by only one simulation (see above). These differences in the projected summer warming and drying between the GCM and the RCM will be discussed in 
Fig. 6 Monthly mean evapotranspiration changes (2071-2100 compared to 19611990) over the Baltic Sea (upper panels), Danube (middle panels) and Rhine catchments (lower panels) as projected by the GCM ECHAM5/MPIOM (left panels) and the RCM REMO (right panels). Max Std denotes the maximum spread $S$ for the corresponding ensembles
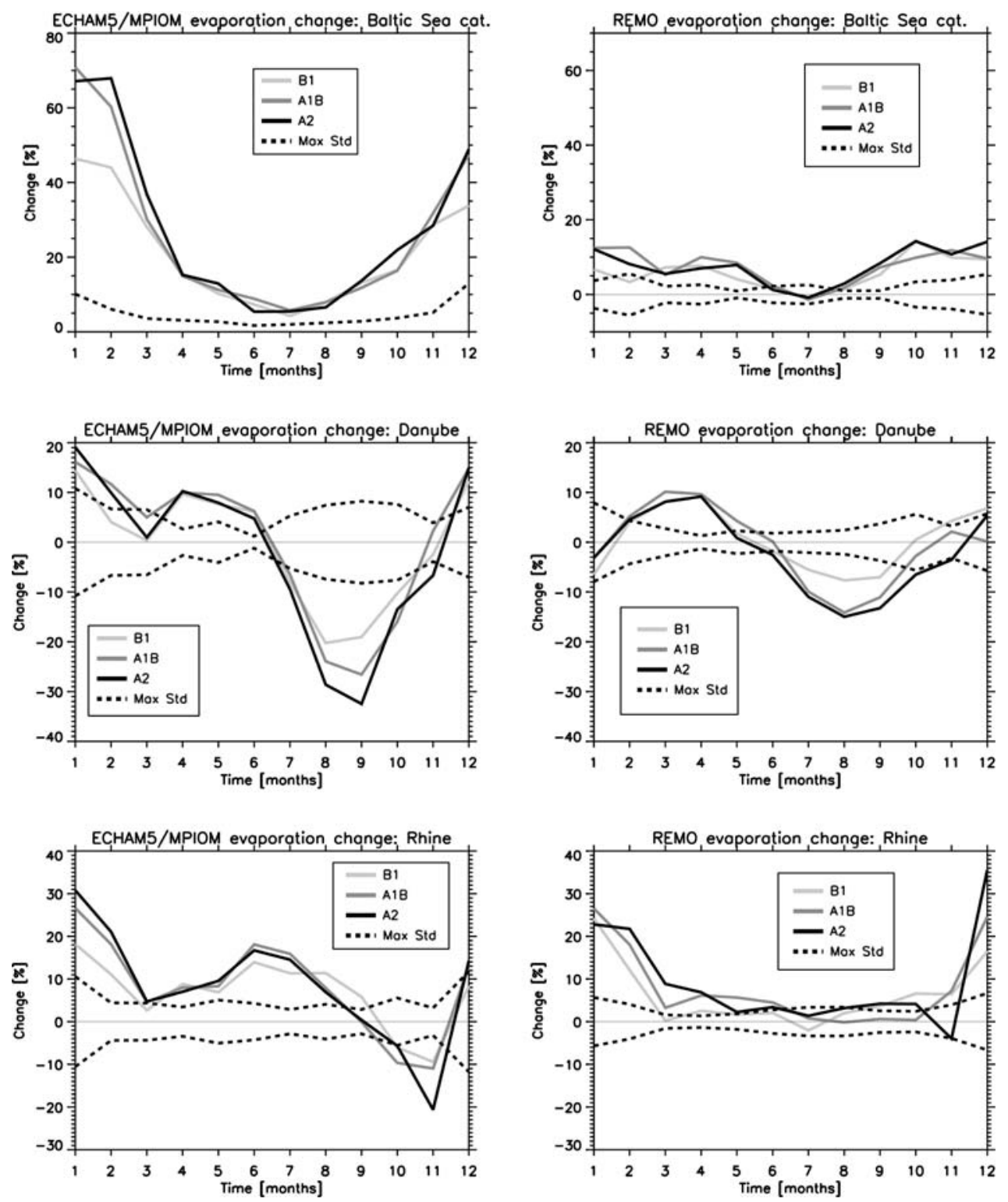

Sect. 5.2. It can be noted (see also Fig. 7) that for both GCM and RCM, the projected runoff decreases are stronger for the Rhine than for the Danube. Albeit the RCM result is consistent to the REMO results obtained in the PRUDENCE project (cf. Sect. 1), it noticeably differs from the reduction in runoff projected by the PRUDENCE multi-model ensemble mean, which is stronger for the Danube than for the Rhine (Hagemann and Jacob 2007).

\section{Discussion}

\subsection{Baltic Sea catchment}

As shown in Sect. 4, the GCM projects a much stronger relative increase in evapotranspiration than the RCM over the Baltic Sea catchment, especially during winter time. Figure $8 \mathrm{a}$ shows that this stronger relative increase $(+60 \%$ compared to $+11 \%$; Fig. 6 ) in the winter is also stronger in absolute amounts $\left(+4,000 \mathrm{~m}^{3} / \mathrm{s}\right.$ compared to $\left.+1,200 \mathrm{~m}^{3} / \mathrm{s}\right)$, which is consistent with the about $1 \mathrm{~K}$ higher projected warming in the A1B scenario of the GCM compared to the RCM. This different behaviour will be discussed and analysed in more detail in the following.

The large difference in the annual evapotranspiration change can be explained by the higher resolution of the RCM. In the RCM the land-sea distribution of the Baltic Sea is much better resolved, and its water surface area is about 19\% larger than in the GCM. This leads to a better representation of the high evaporation from the relatively warm water (note that the RCM uses the SST of the Baltic Sea surface that was simulated by the GCM), and thus of 
Fig. 7 Monthly mean runoff changes (2071-2100 compared to 1961-1990) over the Baltic Sea (upper panels), Danube (middle panels) and Rhine catchments (lower panels) as projected by the GCM ECHAM5/MPIOM (left panels) and the RCM REMO (right panels). Max Std denotes the maximum spread $S$ for the corresponding ensembles
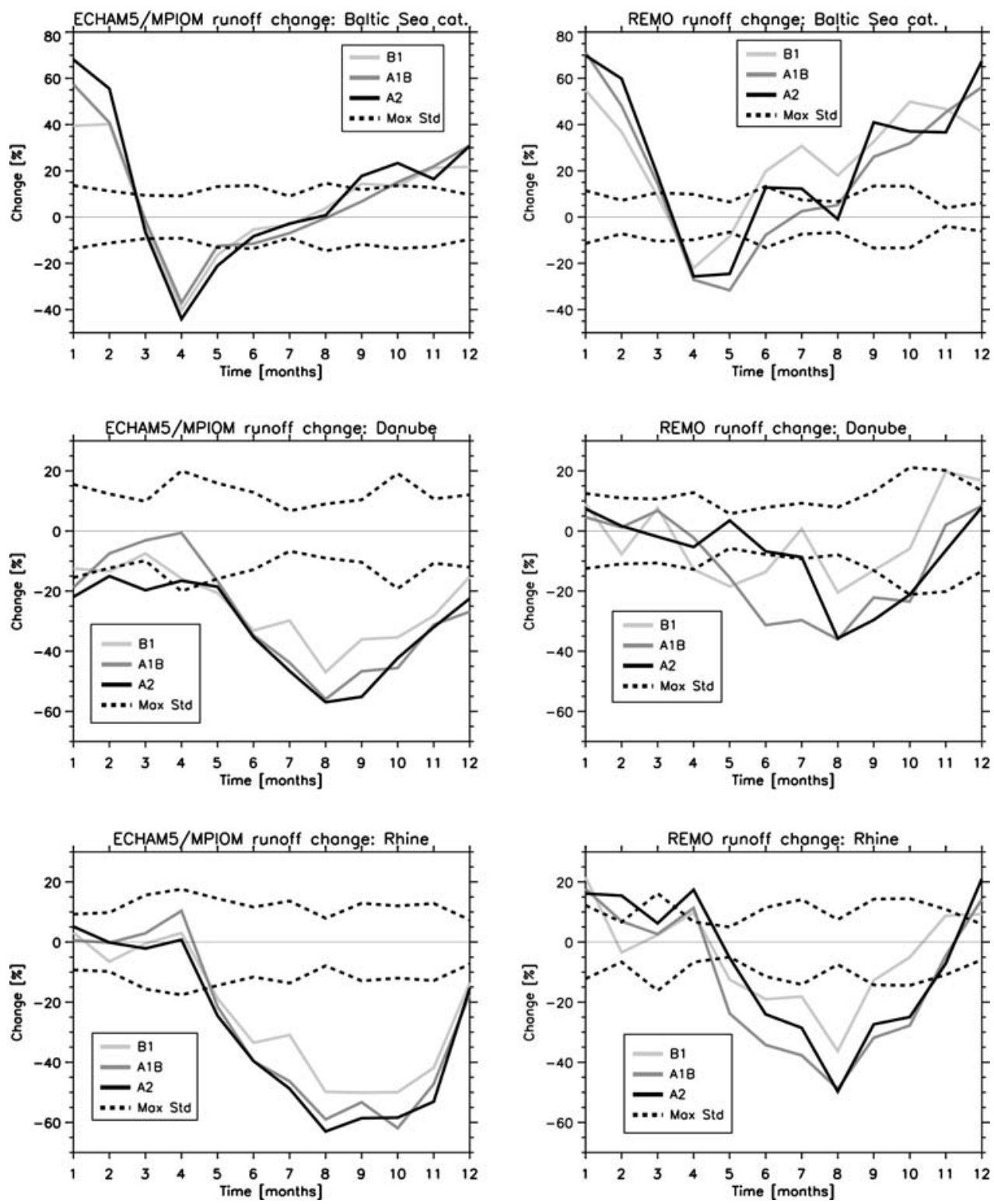

the moistening of the atmosphere from the Baltic Sea. Consequently, the moisture transport from the water to the land is more realistic, thereby causing less water demand of the atmosphere over land. Therefore a smaller increase of evapotranspiration is projected, which in turn leads to a robust increase in runoff due to the projected increase in precipitation.

This explanation certainly holds for most parts of the year, but in the winter evapotranspiration amounts are comparatively low, which puts a challenge to the explanation. However, our explanation is supported by Fig. 9 showing a strong increase in evaporation projected by the RCM only over the Baltic Sea water surface, whereas the evaporation increase over the Baltic Sea catchment land area is much lower. The GCM projects a comparatively lower increase over the water surface than the RCM, and instead the strongest evaporation increase is shown over land in the downstream area of the prevailing winter time atmospheric westerly circulation.

The simulated snow pack does not contribute significantly to the difference between GCM and RCM. The overall amount for current climate (1961-1990; Fig. 8b) agrees quite well between the GCM and the RCM. However, since the melting season starts slightly later in the RCM, the RCM simulates somewhat larger amounts of accumulated snow. But this fact also holds for the simulated snow pack in the A1B scenario at the end of the twenty-first century, where both GCM and RCM project a similar reduction in the snow pack. Also the horizontal patterns of the winter snow pack agree quite well between GCM and RCM for both time periods, except for finer horizontal structures due to the higher RCM resolution and 
Fig. 8 Monthly ensemble means of (a) evapotranspiration, (b) snow pack, (c) cloud cover, and (d) column integrated cloud water over the Baltic Sea catchment for the GCM's and RCM's control climate (C20, 1961-1990, solid lines) and A1B scenario simulations (2071-2100, dashed lines)

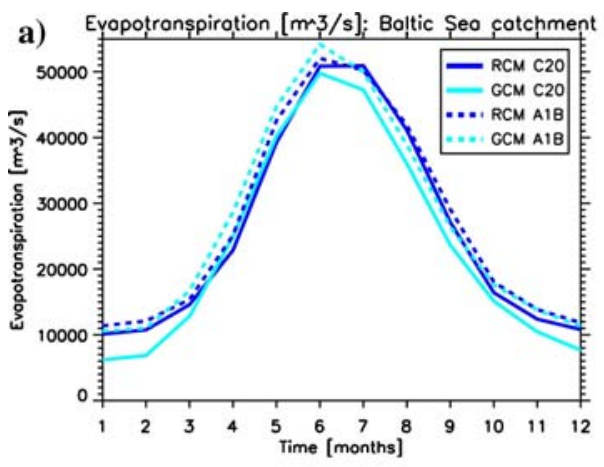

c)

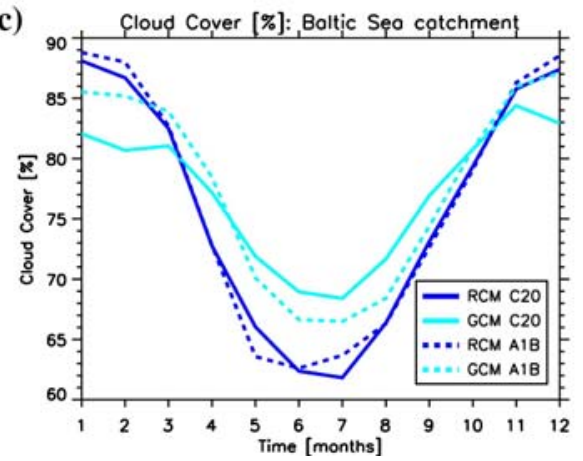

b)

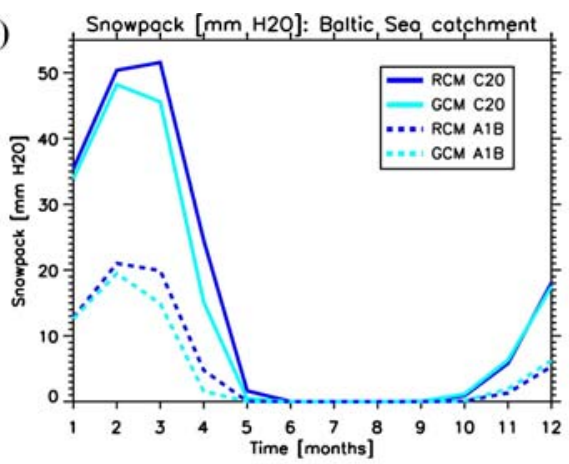

d) Integroted Cloud Woter $[1 . \mathrm{E}-6, \mathrm{~m}]$ : Bolțic Seo cotchment

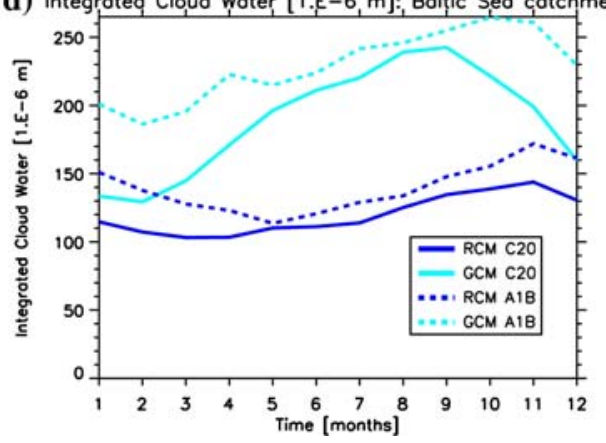

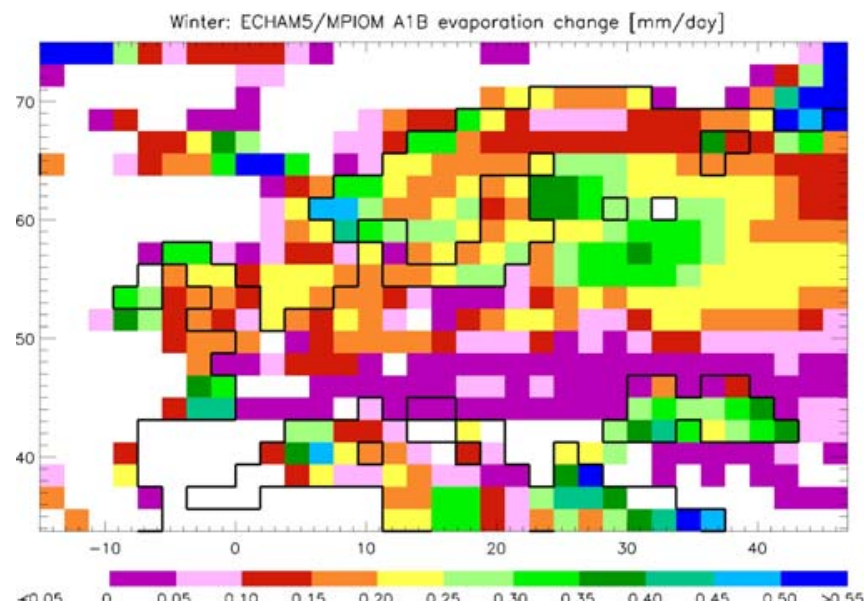

Fig. 9 A1B ensemble mean changes (2071-2100 compared to 19611990) of evapotranspiration in the winter (DJF) as simulated by the GCM ECHAM5/MPIOM (left panel) and the RCM REMO (right panel). Note that both panels show different geographical projections

the tendency to somewhat larger snow amounts simulated by the RCM (not shown).

Considerable differences between the GCM and RCM changes (A1B scenario) can also be found in cloud cover (Fig. 8c) and the column integrated cloud water (ICW) content (Fig. 8d). The RCM projects almost no change in the total cloud cover except for a slight increase in the winter. Here, the GCM projects a strong increase in the winter and a clear reduction during summer time. In the winter, this is fairly consistent with the stronger increase in

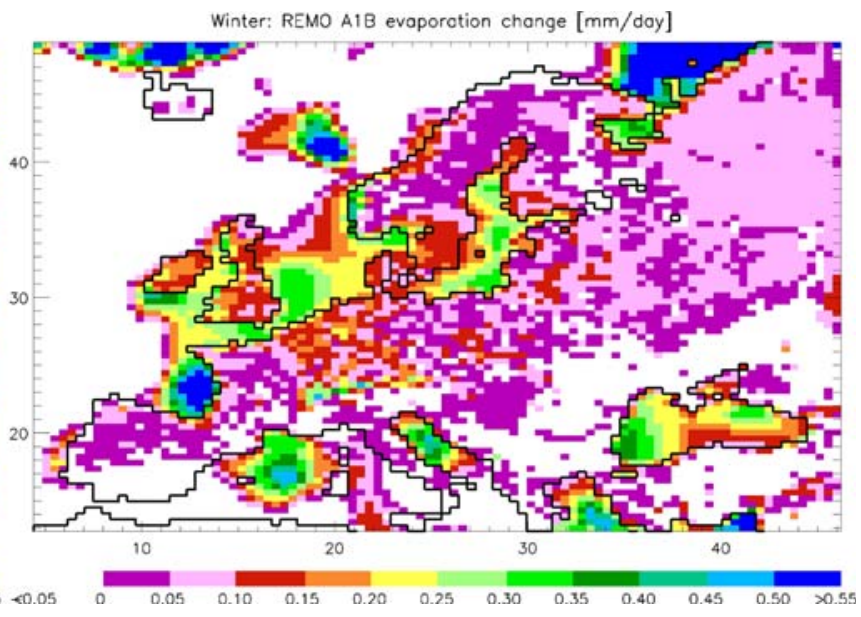

as ECHAM5 uses a regular Gaussian lat/lon grid while REMO uses a rotated lat/lon grid. Thus, the axis tick marks on the left panel denote geographical coordinates while the axis tick marks on the right panel denote the grid box number (index) within the rotated REMO grid

evapotranspiration in the GCM over the whole catchment that leads to a moister atmosphere on larger scales. Therefore, more clouds are formed which lead to a larger warming induced by the enhanced downwelling long wave radiation at the surface. Note that the main effect of increased cloud cover on temperature in the winter is the night time warming. In the summer less cloud cover enhances the warming of the surface. But for the GCM this effect is very likely compensated by the stronger cooling due to the larger increases in the GCM's summer time 
evaporation (Fig. 6, 8a) so that no significant difference in the projected summer warming can be seen between the GCM and the RCM (cf. Fig. 4).

For ICW (Fig. 8d), the RCM projects a general increase that is somewhat larger in winter than in summer. Again the winter time increase projected by the GCM is much stronger. Also the simulated mean annual cycle differs largely between the RCM and the GCM, which is a consequence of the different cloud physics used in the two models. Whether the use of this different cloud physics may not only lead to differences in the current climate but also to differences in future changes is a subject of further studies that are beyond the scope of the present paper.

Even though the large scale forcing is the same for the GCM and RCM, the RCM domain is large enough to allow for differences in dynamical quantities between both models. Thus, part of the differences in the projected changes between the GCM and RCM can also be explained by the differences in the projected circulation patterns in the winter (not shown). Here, the projected North-South pressure gradient over Europe is more pronounced in the GCM than in the RCM, i.e. increasing the high over the Mediterranean and deepening the low over the North Atlantic. On the one hand this leads to stronger westerly winds in the GCM and, thus, to an enhanced evapotranspiration. On the other hand, the North Atlantic influence on Northern Europe is stronger in the GCM projections than in the RCM projections. Therefore more warm and moist air masses are transported into the Baltic Sea catchment, which leads to an enhanced cloud cover, and consequently, higher temperatures (see above). The different changes in the winter pressure patterns in the RCM compared to the GCM may also partially be induced by the better resolved topography.

\subsection{Danube and Rhine}

As shown in Sect. 4, the GCM projects a much stronger drying and about a $1 \mathrm{~K}$ higher warming than the RCM over the Danube and Rhine catchments during the summer. As Fig. 10 shows for the Danube catchment, the future warming leads to an increase in evapotranspiration (upper panels) in the spring and the early summer. This additionally dries the soil (middle panels), so that in the late summer and autumn the evaporative demand of the atmosphere cannot be fulfilled, which leads to a projected reduction of evapotranspiration. As the projected reduction in precipitation is stronger in the GCM than in the RCM, the drying of the soil is also stronger. Noteworthy is that although the mean soil moisture in the current climate is larger in the GCM, based on the A1B scenario it is projected to drop clearly below the state of the RCM. Thus, the reduction in evapotranspiration is also stronger, leading to less evaporative cooling of the surface and, hence, an enhanced warming.

Note that for the Rhine catchment, despite of the stronger projected drying, the GCM soil in the A1B scenario is wetter than the RCM soil in the first half of the year (see below). This explains why the projected increase in evapotranspiration is extended to the end of summer by the GCM. It can also be seen that for both, GCM and RCM, the projected reduction in soil moisture is larger over the Rhine catchment than over the Danube catchment. This is related to the fact that the current mean state of the soil is generally wetter in the Rhine catchment (88.6 and $86.1 \%$ for GCM and RCM control period, respectively) than in the Danube catchment (70.9 and $67.1 \%$ ), thereby leading to a larger buffer capacity of the soil in the Rhine catchment (cf. Sect. 4).

The different behaviour of GCM and RCM is likely to be caused by the fact that the higher resolution of the RCM leads to a better representation of local scale processes including soil moisture feedbacks to the atmosphere. Seneviratne et al. (2006) stated that due to the northward shift of climatic regimes in Europe in response to increasing anthropogenic GHG concentrations, a new transitional climate zone between dry and wet climates with strong land-atmosphere coupling will be created in central and eastern Europe. They also pointed out that land-atmosphere coupling is significantly affected by global warming and is itself a key player for climate change, thereby highlighting the importance of soil-moisture-temperature feedbacks (in addition to soil-moistureprecipitation feedbacks) for future climate changes over this region. Van den Hurk et al. (2005) stated that in many cases models overemphasize the positive land-atmosphere feedback that leads to a dry soil, strong evaporation stress and reduced precipitation, which poses severe problems in the interpretation of hydrological aspects of climate change in future GHG emission scenarios. In this respect, the so called "summer drying problem" (the too dry and too warm simulation of the summertime climate over central and eastern Europe) is often reported for many GCMs and RCMs. Hagemann et al. (2004) considered this problem over the Danube area in more detail for five different RCMs.

Figure 11 shows that the coupled GCM ECHAM5/ MPIOM has a relatively strong summer drying problem in both catchments, which is consistent with the behaviour of the atmospheric GCM ECHAM5 forced by observed SST, as shown for the Danube by Hagemann et al. (2006). The problem is much less pronounced in the RCM, which even shows some overestimation of summer rainfall over the Rhine catchment. Within PRUDENCE, results of Hagemann and Jacob (2007) indicated that the use of RCMs can overcome problems that a driving GCM might have with 
Fig. 10 Monthly ensemble means of evapotranspiration (upper panels), relative soil moisture (middle panels) and accumulated snowpack (lower panels) over the Danube (left panels) and Rhine (right panels) catchments for the GCM's and RCM's control climate (C20, 1961-1990, solid lines) and A1B scenario simulations (2071-2100, dashed lines). The relative soil moisture is defined as the soil moisture content divided by the field capacity, which is the maximum soil water holding capacity in the land surface schemes of ECHAM5 and REMO
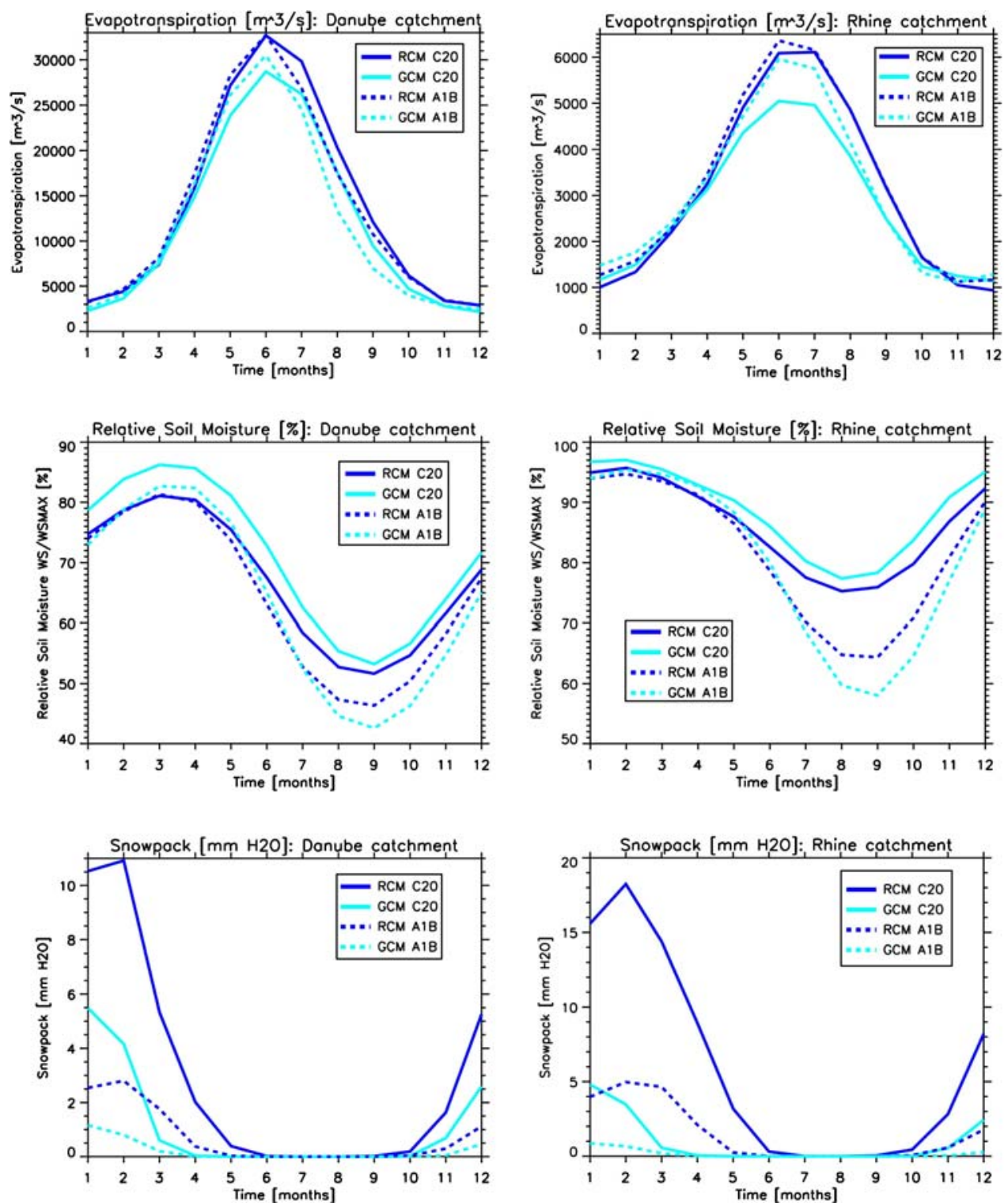

the representation of local scale processes or parameterizations. This supports that the RCM has the potential for an improved simulation of soil moisture feedbacks to the atmosphere, which in turn leads to the lower projected summer time warming and drying than projected by the GCM.

It was mentioned above that in the Rhine catchment the GCM soil in the A1B scenario is wetter than the RCM soil in the first half of the year although the GCM projects a stronger drying during the summer and in the annual mean. From November to April comparable increases in precipitation (11.8 and 15\%) and evaporation (9 and 11.1\%) are projected by the GCM and the RCM. But the projected changes in runoff $(-8.5$ and $+8.6 \%)$ differ, which means that more water is infiltrated into the soil in the GCM $(+363 \%)$ than in the RCM $(+113 \%)$. Due to its finer resolution the RCM better resolves the fine scale orographic structures in the Alps so that a larger amount of high and, thus, cold grid boxes is included in the Alpine region. This is not the case for the coarse GCM orography. Therefore the RCM has probably a considerable amount of snow cover over the Alps during November-April, which is about six times larger than in the GCM for the current climate and largely reduced in the A1B scenario (Fig. 10, lower panels). Consequently a substantial part of the increased RCM precipitation is stored in the snow pack and then released during snow melt events that are usually accompanied by large runoff generation, as large snow melt fluxes occur during a relatively short time. In the GCM, most parts of the increased precipitation enter the surface runoff / infiltration process more evenly distributed in time so that usually infiltration prevails, which moistens 


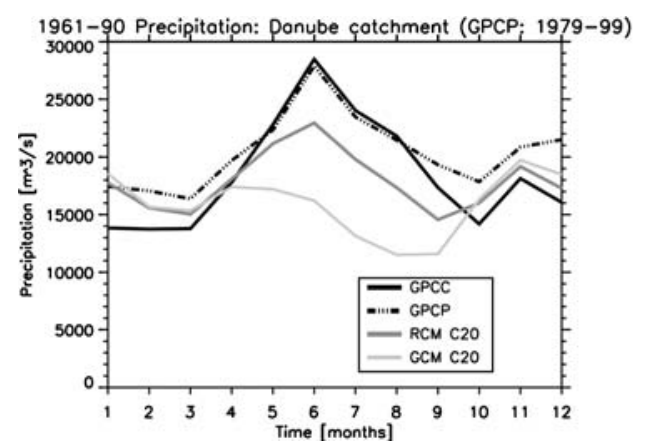

Fig. 11 Observed and simulated monthly ensemble mean precipitation over the Danube (left panel) and Rhine (right panel) catchment for the control climate 1961-1990. Observations are taken from the Global Precipitation Climatology Centre (GPCC; Fuchs et al. 2007) at $0.5^{\circ}$ resolution (uncorrected for the systematic undercatch of measurement gauges), and from the Global Precipitation Climatology

the soil and, hence, leads to a wetter soil than in the RCM A1B scenario during the first half of the year. To a less extent this effect can also be seen for the Danube catchment. In addition the different behaviour of the RCM in the winter and early spring might also be supported by the better resolved soil moisture capacity structures.

If the projected changes in the pressure patterns are considered over the regional domain (not shown) the GCM shows a slightly (less than $0.5 \mathrm{hPa}$ ) stronger influence of high pressure systems than the RCM, which might support a somewhat stronger continental influence on the climate over central and south-eastern Europe. This would also further the warming and drying, especially during the summer and autumn. As mentioned in Sect. 5.1, the RCM domain is large enough to allow for differences in dynamical quantities between the GCM and the RCM. Thus, the stronger warming in the GCM may also have caused the small differences in the pressure patterns between both models.

\section{Summary and conclusions}

In the present study, we have analysed the robustness of the climate change signal in the hydrological cycle over the large European catchments of Baltic Sea (land only), Danube and Rhine. The projected climate changes were obtained from an ensemble of coupled atmosphere-ocean simulations using the GCM ECHAM5/MPIOM and downscaled simulations over Europe using the RCM REMO. In this respect, a robust climate change signal was defined as a projected change (2071-2100 compared to 1961-90) that is larger than the spread representing the natural climate variability in these models.

The analysis of the annual mean changes yielded a robust increase in all components of the terrestrial water

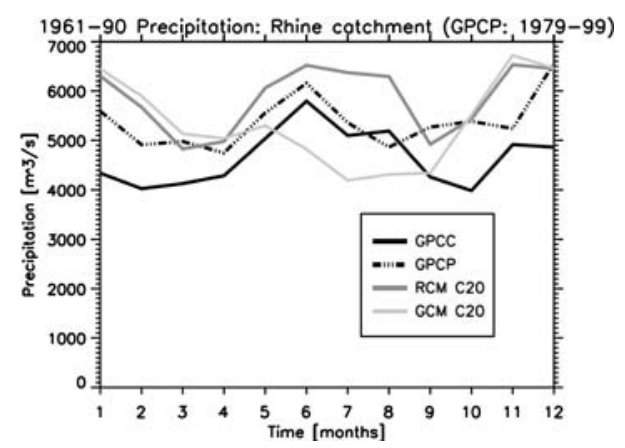

Project (GPCP; Huffman et al. 1997) at $2.5^{\circ}$ resolution (corrected but where it is known that this correction is too large (Rudolf and Rubel 2005)). Since GPCP data were not available for the control climate, the period 1979-1999 was used instead. It was chosen to show both observations to reflect the uncertainty in precipitation datasets

balance over the Baltic Sea catchment, an overall robust increase in evapotranspiration except for the Danube catchment, and a robust decrease of runoff for Danube and Rhine in the GCM. The latter is much smaller in the RCM and not even robust for the Danube catchment. In addition, pronounced robust seasonal signals were found, even in cases where the projected signal in the annual mean is not robust. The projected future warming at the end of this century is robust in all month over all catchments. Over the Baltic Sea catchment, a general increase of precipitation is projected except for the summer, which is accompanied by a general increase in evapotranspiration and an increase in runoff in the autumn and winter. For the Danube and Rhine catchments, a decrease of summer time precipitation and runoff is projected. For the Danube, the drying of soil moisture leads to reduced evapotranspiration in the summer, while the wetter mean state of the Rhine catchment yields larger buffer capacities of soil water storage that cause a robust evapotranspiration decrease only in the late autumn in the GCM simulations. In addition, robust increases in evapotranspiration are projected in the winter (except for the RCM over the Danube catchment) and spring. The general changes agree well with the large-scale climate change patterns over Europe obtained in previous studies (e.g. within PRUDENCE, cf. Sect. 1).

Noticeable differences in the robustness of the climate change signals between the GCM and RCM simulations are related to a stronger warming of about $1 \mathrm{~K}$ projected by the GCM in the winter over the Baltic Sea catchment and in the summer over the Danube and Rhine catchments. The first is accompanied by a much larger evapotranspiration increase in the GCM, especially in the winter. The latter is associated with a stronger projected summer drying in the two catchments. The better description of surface processes, higher resolution and non-linear scale interactions in the RCM gives a better representation of present day 
climate and hence a more credible climate change projection. This is even along the lines of thoughts provided in the IPCC AR4 global and regional climate change chapters (IPCC 2007). Over the Baltic Sea catchment, the RCM has an improved representation of the land sea contrast, and, hence, improved related moisture transport processes between water and land areas. Over the Danube and Rhine catchments, the better distribution of soil moisture leads to an improved representation of soil moisture feedbacks to the atmosphere.

How RCM projections behave, when different scenarios and different GCM forcing are used, is currently being investigated within the EU project ENSEMBLES that started in September 2004. Here, a main issue is to determine whether the use of several RCMs with different GCM forcings actually results in more confidence in the overall results. The hydrological analyses conducted in the present study and in PRUDENCE (e.g., by Hagemann and Jacob 2007) will be continued within the EU project WATCH. Here, different GCM and RCM simulations (ideally if forced by different GCMs) from the ENSEMBLES project shall be analysed in a similar way. These analyses will provide useful background for studies on uncertainties in the hydrological cycle and its future changes, especially if hydrological models are forced with climate model input, such as it is planned in the WATCH project.

Acknowledgments This study was partially supported by funding from the European Union within the WATCH project (contract No. 036946). We would like to thank Jochem Marotzke who supported this study, and we are very grateful to all members of the MPI-M earth system modeling team who contributed to the realization of the global IPCC simulations with ECHAM5/MPIOM and the regional downscaling simulations with REMO.

Open Access This article is distributed under the terms of the Creative Commons Attribution Noncommercial License which permits any noncommercial use, distribution, and reproduction in any medium, provided the original author(s) and source are credited.

\section{References}

Christensen JH, Christensen OB (2007) A summary of the PRUDENCE model projections of changes in European climate by the end of this century. Clim Change (Prudence Special Issue) 81(Suppl 1):7-30. doi: 10.1007/s10584-006-9210-7

Christensen JH, Carter TR, Rummukainen M, Amanatidis G (2007) Evaluating the performance and utility of climate models: the PRUDENCE project. Clim Change (Prudence Special Issue) 81(Supplement 1):1-6. doi:10.1007/s10584-006-9211-6

Cubasch U, Waszkewitz J, Hegerl G, Perlwitz J (1995) Regional climate changes as simulated in time-slice experiments. Clim Change 31:273-304

Cubasch U, Voss R, Mikolajewicz U (2000) Precipitation: a parameter changing climate and modified by climate change. Clim Change 46(3):257-276
Déqué M., Piedelievre JP (1995) High resolution climate simulation over Europe. Clim Dyn 11:321-339

Déqué M, Rowell D, Lüthi D, Giorgi F, Christensen JH, Rockel B, Jacob D, Kjellstrom E, de Castro M, van den Hurk B (2007) An intercomparison of regional climate models for Europe: assessing uncertainties in model projections. Clim Change (Prudence Special Issue) 81(Suppl 1):53-70. doi: 10.1007/s10584-006-9228-x

Dümenil L, Todini E (1992) A rainfall-runoff scheme for use in the Hamburg climate model. In: Kane JP (ed) Advances in theoretical hydrology - a tribute to James Dooge, Elsevier, Amsterdam, pp129-157

Fuchs T, Schneider U, Rudolf B (2007) Global precipitation analysis products of the GPCC. Global Precipitation Climatology Centre (GPCC). Deutscher Wetterdienst, Offenbach

Giorgi F (2006) Regional climate modeling: status and perspectives. J Phys IV Fr 139:101-118. doi:10.1051/jp4:2006139008

Giorgi F, Mearns LO (1999) Introduction to special section: regional climate modeling revisited. J Geophys Res 104:6335-6352

Graham LP, Hagemann S, Jaun S, Beniston M (2007) On interpreting hydrological change from regional climate models. Climatic Change (Prudence Special Issue) 81(Supplement 1):97-122 doi: 10.1007/s10584-006-9217-0

Hagemann S (2002) An improved land surface parameter dataset for global and regional climate models. Max Planck Institute for Meteorology Rep 336. (available from MPI for Meteorology, Bundesstr. 53, 20146 Hamburg, Germany)

Hagemann S, Dümenil L (1998) A parameterization of the lateral waterflow for the global scale. Clim Dyn 14:17-31

Hagemann S, Dümenil Gates L (2003) Improving a subgrid runoff parameterization scheme for climate models by the use of high resolution data derived from satellite observations. Clim Dyn 21:349-359

Hagemann S, Jacob D (2007) Gradient in the climate change signal of European discharge predicted by a multi-model ensemble. Clim Change (Prudence Special Issue) 81(Suppl 1):309-327 doi: 10.1007/s10584-006-9225-0

Hagemann S, Machenhauer B, Jones R., Christensen OB, Déqué M, Jacob D, Vidale PL (2004) Evaluation of water and energy budgets in regional climate models applied over Europe. Clim Dyn 23:547-567

Hagemann S, Arpe K, Roeckner E (2006) Evaluation of the hydrological cycle in the ECHAM5 model. J Clim 19:3810 3827

Hirschi M, Seneviratne SI, Hagemann S, Schär C (2007) Analysis of seasonal terrestrial water storage variations in regional climate simulations over Europe. J Geophys Res 112:D22109. doi: 10.1029/2006JD008338

Houghton JT, Ding Y, Griggs DJ, Noguer M, van der Linden PJ, Xiaosu D (2001) Climate Change 2001: The scientific basis. Contribution of working group I to the third assessment report of the governmental panel on climate change, Cambridge University Press, Cambridge

Huffman GJ, Adler RF, Arkin A, Chang A, Ferraro R, Gruber A, Janowiak J, Joyce RJ, McNab A, Rudolf B, Schneider U, Xie P (1997) The global precipitation climatology project (GPCP) combined precipitation data set. Bul Am Meteorol Soc 78:5-20

IPCC (2007) Climate Change 2007: The physical science basis. Contribution of working group I to the fourth assessment report of the intergovernmental panel on climate change. In: Solomon S, Qin D, Manning M, Chen Z, Marquis M, Averyt KB, Tignor M, Miller HL (eds.) Cambridge University Press, Cambridge, $p$ 996

Jacob D (2001) A note to the simulation of the annual and interannual variability of the water budget over the Baltic Sea drainage basin. Meteorol Atmos Phys 77:61-73 
Jungclaus JH, Botzet M, Haak H, Keenlyside N, Luo J-J, Latif M, Marotzke J, Mikolajewicz U, Roeckner E (2006) Ocean circulation and tropical variability in the coupled model ECHAM5/MPI-OM. J Clim 19:3952-3972

Kennett E, Rowell D, Jones R, Buonomo E (2008) Robustness of future changes in local precipitation extremes. J Clim. doi: 10.1175/2008JCLI2082.1

Lohmann U, Roeckner E (1996) Design and performance of a new cloud microphysics scheme developed for the ECHAM4 general circulation model. Clim Dyn 12:557-572

Nakicenovic N, Alcamo J, Davis G, de Vries B, Fenhann J, Gaffin S, Gregory K, Grübler A, Jung TY, Kram T, La Rovere EL, Michaelis L, Mori S, Morita T, Pepper W, Pitcher H, Price L, Raihi K, Roehrl A, Rogner H-H, Sankovski A, Schlesinger M, Shukla P, Smith S, Swart R, van Rooijen S, Victor N, Dadi Z (2000) IPCC special report on emissions scenarios. Cambridge University Press, Cambridge

Pope VD, Gallani ML, Rowntree PR, Stratton RA (2000) The impact of new physical parametrizations in the Hadley Centre climate model: HadAM3. Clim Dyn 16:123-146

Räisänen J, Hansson U, Ullerstig A, Döscher R, Graham LP, Jones C, Meier HEM, Samuelsson P, Willén U (2004) European climate in the late twenty-first century: regional simulations with two driving global models and two forcing scenarios. Clim Dyn 22:13-31

Rechid D, Raddatz TJ, Jacob D (2008) Parameterization of snow-free land surface albedo as a function of vegetation phenology based on MODIS data and applied in climate modelling. Theor Appl Climatol (in press)

Roeckner E, Arpe K, Bengtsson L, Christoph M, Claussen M, Dümenil L, Esch M, Giorgetta M, Schlese U, Schulzweida U (1996) The atmospheric general circulation model ECHAM-4: Model description and simulation of the present day climate. Max Planck Institute for Meteorology Rep 218. (available from MPI for Meteorology, Bundesstr. 53, 20146 Hamburg, Germany)

Roeckner E, Bäuml G, Bonaventura L, Brokopf R, Esch M, Giorgetta M, Hagemann S, Kirchner I, Kornblueh L, Manzini E, Rhodin A, Schlese U, Schulzweida U, Tompkins A (2003) The atmospheric general circulation model ECHAM5. Part I: model description. Max Planck Institute for Meteorology Rep 349, p 127 (available from MPI for Meteorology, Bundesstr. 53, 20146 Hamburg, Germany)
Roesch A, Wild M, Gilgen H, Ohmura A (2001) A new snow cover fraction parameterization for the ECHAM4 GCM. Clim Dyn 17:933-946

Rowell DP (2005) A scenario of European climate change for the late 21st century: seasonal means and interannual variability. Clim Dyn 25:837-84

Rowell DP (2006) A demonstration of the uncertainty in projections of UK climate change resulting from regional model formulation. Clim Change 79:243-257

Rudolf B, Rubel F (2005) Global precipitation. In: Hantel M (ed) Observed global climate, Chap. 11. Landolt-Boernstein: numerical data and functional relationships in science and technology—new series, Group 5:Geophysics, vol 6, Springer, Berlin, p 567

Rummukainen M, Räisänen J, Bringfelt B, Ullerstig A, Omstedt A, Willén U, Hansson U, Jones C (2001) A regional climate model for northern Europe: model description and results from the downscaling of two GCM control simulations. Clim Dyn 17:339-359

Semmler T, Jacob D, Schlünzen KH, Podzun R (2004) Influence of Sea Ice Treatment in a Regional Climate Model on Boundary Layer Values in the Fram Strait Region. Mon Wea Rev 132:985999

Seneviratne SI, Lüthi D, Litschi M, Schär C (2006) Land-atmosphere coupling and climate change in Europe. Nature 443(7108):205209

Sorooshian S, Roads J, Polcher J, Schiffer R, Lawford R, Try P, Rossow W, Sommeria G (2005) Water and energy cycles: investigating the links. Bull World Meteorol Organ 54(2):5864

Tompkins A (2002) A prognostic parameterization for the subgridscale variability of water vapor and clouds in large-scale models and its use to diagnose cloud cover. J Atmos Sci 59:1917-1942

van den Hurk B, Hirschi M, Schär C, Lenderink G, van Meijgaard E, van Ulden A, Rockel B, Hagemann S, Graham LP, Kjellström E, Jones R (2005) Soil control on runoff response to climate change in regional climate model simulations. J Clim 18:3536-3551

Wilby RL, Wigley TML, Conway D, Jones PD, Hewitson BC, Main J, Wilks DS (1998) Statistical downscaling of general circulation model output: a comparison of methods. Water Resour Res 34:2995-3008 